\title{
Syphilitica Roseola in HIV-Infected Patient
}

\section{Riyanto $\mathrm{P}^{*}$}

Department of Dermatology and Venereology, Diponegoro University/Kariadi Hospital, Indonesia

*Corresponding author: Dr. Puguh Riyanto, MD, DV, Department of Dermatology and Venereology, Faculty of Medicine, Diponegoro University/Kariadi Hospital; Semarang, Indonesia, Tel: 0816650792; E-mail: Puguhungaran@gmail.com

\section{Case Report \\ Volume 2 Issue 2}

Received Date: May 06, 2017

Published Date: May 17, 2017

DOI: $10.23880 /$ cdoaj16000122

\section{Abstract}

Syphilis roseola is the main symptoms of the secondary syphilis, in the form of multiple, asymptomatic, light pink erythema of $5 \mathrm{~mm}$ to $20 \mathrm{~mm}$ in diameter occur on the whole body surface, markedly on the palms and soles. The patient is a 29-years-old unmarried man with syphilis roseola and HIV. Venereal Disease Research Laboratory (VDRL) titer > 1: 64, and Treponemal Pallidum Haem agglutination (TPHA) titer > 1: 640. Viral load not detected, CD4 590 cells/ $\mu$. This patient received intramuscular single dose of 2.4 million units of Benzathine Penicillin G, a combination of Tenofovir 300 mg / 24 hours, Lamivudine 300 mg / 24 hours, Efavirens 600 mg / 24 hours and no topical therapeutic. After 6 months therapy improves generalist status, no skin lesions and CD4 repair to 630 cells / $\mu$ l.

Keywords: Syphilis Roseola; HIV

\section{Introduction}

Syphilis is a systemic infection caused by Treponema Pallidum subspecies Pallidum, from Spirochaetae family. Synonimes of syphilis are lues venera. Syphilis is usually transmitted sexual contact, except congenital syphilis which is transmitted by transplacental [1-5]. by:

Syphilis increases the risk of HIV transmission 2-5 fold

1) Primary syphilis with genital ulcers symptom, increase HIV penetration

2) The disruption of epidermal or mucosal barriers caused by syphilis ulcers might bleed easily during intercourse, increase the risk of HIV transmission

3) Inflammation from genital ulcers activated Cluster of Differentiation 4 cells (CD4), facilitates HIV infection, replication, and spread throughout the body. Among
$51.2 \%$ of MSM with syphilis are also co-infected with HIV $[6,7]$.

Syphilis can be classified into congenital syphilis and acquired syphilis. There are 3 categories of congenital syphilis: which is early congenital syphilis in a child aged $<2$ years, late congenital syphilis occurring in a child $>2$ years, and stigmata of syphilitic. According to the clinical and epidemiological features, syphilis can be classified into: primary syphilis, secondary syphilis, early and latent late syphilis, tertiary syphilis, cardiovascular syphilis and neurosyphilis $[4,8,9]$.

The initial lesion of syphilis is a red macule, than become papule, erosive, durum ulcer (hunterian chancre) with central ulcerative appears at the site of venereal contact, 10-90 days after exposure. In the absence of treatment, syphilitic chancres heal spontaneously within 3-6 weeks, appropriated treatment heal without scar 
within 1-2 weeks [2,9]. Serological test for syphilis could still non reactive when syphilitic ulcers occurred for the first time, and then begin to become reactive 1-4 weeks after infection. Secondary syphilis occurred within 6-8 weeks (up to 6 months after exposure) characterized by rash symmetrically on the trunk and extremities, localized or diffuse as a result of hematogenous spread called disseminate syphilis $[2,3]$.

Organs such as mucocutaneous, generalized limphadenopathy persist, eyes, liver, bone, and neuron might be involve in secondary syphilis $[2,3,5]$. Skin manifestation of secondary syphilis characterized by red macules, papules, papulosquamous, and pustules symmetrically, discrete. No itchy, most accompanied by inguinal lymphadenopaty $[1,4]$.

Serological tests for syphilis is an examination that is used to diagnosis, screening, and assessing the progress treatment of syphilis $[2,6,9]$. Serological test for syphilis include non treponemal test VDRL, and treponemal test TPHA $[2,5,10]$.

Secondary syphilis can be treated with Benzathine Penicillin G intramuscular and single dose of 2.4 million units, or Procain Penicillin G in aqua 0.6 million units/day intramuscular for 10 days. For person who have allergic to penicillincan be treated with tetracycline $500 \mathrm{mg} 4$ times/ day, or erythromycine $500 \mathrm{mg} 4$ times/day, or doxycycline $100 \mathrm{mg}$ twice daily, for 15 days. Benzathine penicillin G intramuscular is the recommended treatment for all stages of syphilis, the treatment dose dependent on stage of disease and clinical manifestation. The treatment for secondary syphilis with or without co-infection with HIV is an intramuscular and single dose of 2,4 million units of benzathine penicillin $G[4,8,9,11,12]$.

The aim of this case report is to understand about the case and the management of skin manifestation in secondary syphilis (Syphilitica roseola) in HIV.

\section{Case Report}

A 26-years-old unmarried man, Javanese, Indonesian, with symptoms of brown patches on his soles. History of this disease is approximately 3 weeks ago, brown patches were occurred on his soles. At the beginning, that brown patches were reddish, just a few patches. He did not feel itchy, or pain. He felt undisrupted, so he did not come to the doctor. He was referred from internal medicine department to dermatovenereology department on the day he came to take his antiretroviral (ARV) therapy.
There were no painless ulcers on his genitalia at that time. This is his first time having this kind of disease.

He had history of painless ulcer on his penis 6 months ago that recovered without treatment. Patient is a homosexual who often have multiple sexual partners and unsafe sexual intercourse by mouth and anal since 5 years ago. No history of tattoo, blood transfusion, or intravenous drug. No history of the foot was often submerged in water. No history of new footwear, or materials applied to the soles. No history of sneezing, urticaria in the morning. No history of food or drug allergy. No family history that has been complaint like he was before.

In 2014, he was diagnosed with HIV when he was stayed at Dr. Sardjito Hospital in Jogjakarta for his unhealed fever, and the doctor gave him an antiretroviral (ARV) therapy. He continued his ARV therapy in Dr. Kariadi Hospital since 1 year. He was complaint loss 10 kilograms of his body weight and often had fever, no history of unhealed cough, or night sweat, 6 months before he was diagnosed as HIV.

Clinical examination: conscious and oriented, height: $176 \mathrm{~cm}$, weight: $55 \mathrm{~kg}$. Lymphadenopathy on neck, both axillae and both inguinal, multiple, painless. Dermatologic status: both left and right soles are hyperpigmentation macules, oval, discrete, no scales (Figure 1).

\begin{tabular}{|c|c|c|}
\hline & Results & Normal range \\
\hline Hemoglobin & $12.7 \mathrm{~g} / \mathrm{dL}$ & $13.00-16.00 \mathrm{~g} / \mathrm{dL}$ \\
\hline Hematocrite & $38.39 \%$ & $40-54 \%$ \\
\hline Erytrocyte & $4.30 \times 10^{6} / \mathrm{uL}$ & $4.4-5.9 \times 10^{6} / \mathrm{uL}$ \\
\hline Leucocyte & $6.7 \times 10^{3} / \mathrm{uL}$ & $3.6-10 \times 10^{3} / \mathrm{uL}$ \\
\hline Platelete & $356000 / \mathrm{uL}$ & $150000-400000 / \mathrm{uL}$ \\
\hline $\begin{array}{c}\text { Random } \\
\text { glucose test }\end{array}$ & $95 \mathrm{mg} / \mathrm{dL}$ & $80-160 \mathrm{mg} / \mathrm{dL}$ \\
\hline Urea & $16 \mathrm{mg} / \mathrm{dL}$ & $15-39 \mathrm{mg} / \mathrm{dL}$ \\
\hline Creatinin & $0.8 \mathrm{mg} / \mathrm{dL}$ & $0.60-1.30 \mathrm{mg} / \mathrm{dL}$ \\
\hline SGOT & $24 \mathrm{U} / \mathrm{L}$ & $15-34 \mathrm{U} / \mathrm{L}$ \\
\hline SGPT & $32 \mathrm{U} / \mathrm{L}$ & $15-60 \mathrm{U} / \mathrm{L}$ \\
\hline
\end{tabular}

Table 1: Routine blood test and chemical blood test.

$10 \% \mathrm{KOH}$ examination No spora, no hyfa. Serology tests for syphilis results are VDRL positive, titer > 1: 64, TPHA are positive, titer $>1: 640$. Immunoserology tests: Viral load not detected CD4 590 cells/ $\mu$ l (Table 2). 


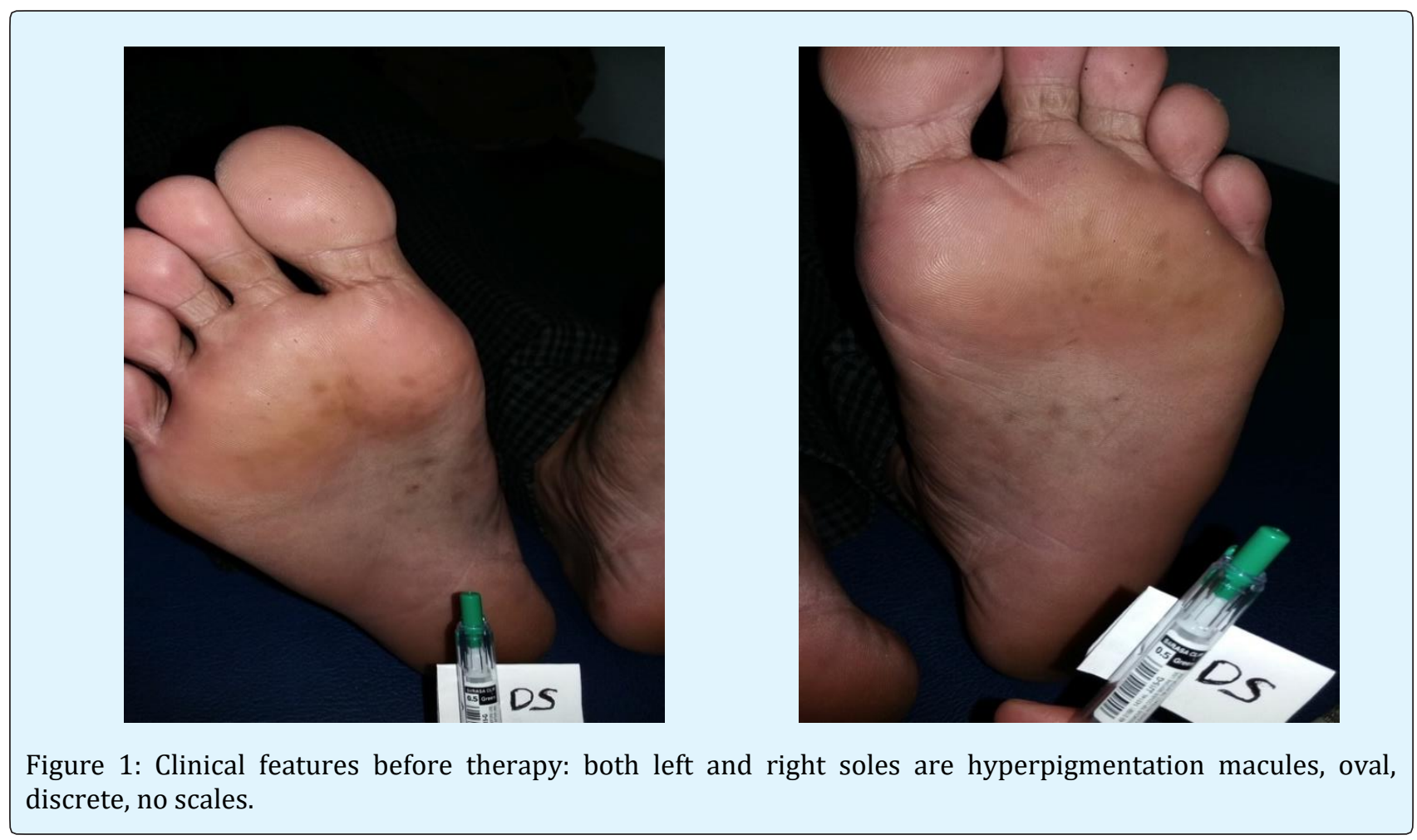

Results of Routine blood test and chemical blood test, slightly anemic (Table 1).

\begin{tabular}{|c|c|c|}
\hline Test & Results & Normal range \\
\hline Viral load & $\begin{array}{c}\text { Not detected } \\
\text { (level of detected: } \\
>40 \text { copies / ml }\end{array}$ & \\
\hline CD4 & & $\begin{array}{c}410-1590 \\
\text { cells } / \mu l\end{array}$ \\
\hline
\end{tabular}

Table 2: Immunoserology tests

This patient received intramuscular single dose of 2.4 million units of Benzathine Penicillin G, a combination of retroviral therapy Tenofovir $300 \mathrm{mg} / 24$ hours, Lamivudine $300 \mathrm{mg} / 24$ hours, Efavirens $600 \mathrm{mg} / 24$ hours and no topical therapeutic. After 6 months therapy there was clinical and laboratory improvement, good generalist status and no skin lesions. Serology tests for syphilis results: VDRL titer remains positive> 1: 4, TPHA titer positive> 1: 640 Immunoserology tests: CD4: 630 cells/ $\mu$ l (Figure 2).

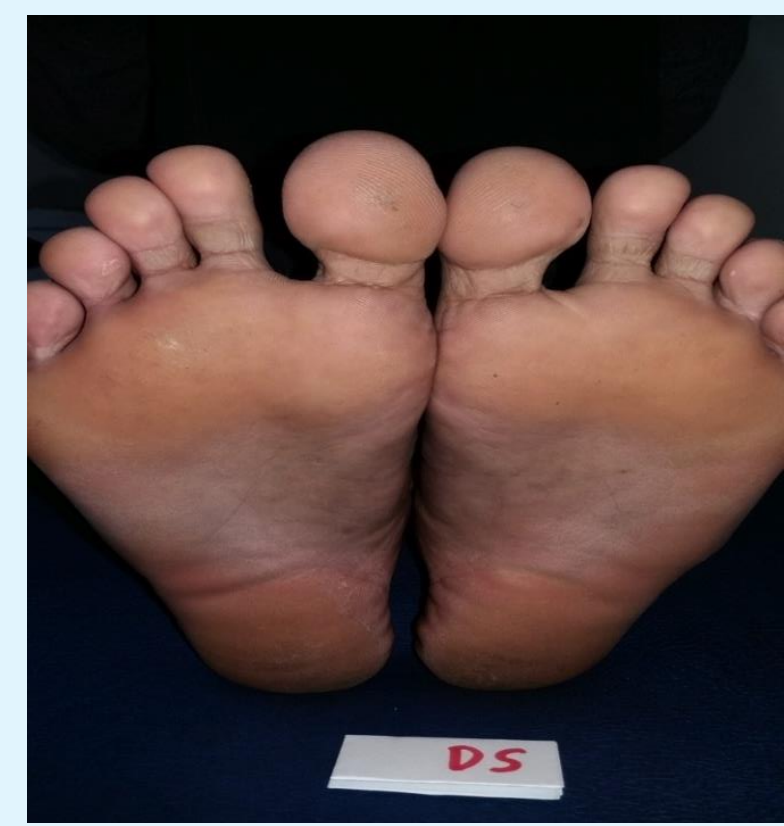

Figure 2: After 6 months of therapy: both left and right soles no lesions. 


\section{Discussion}

Syphilitic Roseola diagnosis is made by anamnesis, clinical and serological examination. From anamnesis, we obtained that the patient is a 29-years-old unmarried man with a history of promiscuity and painless ulcer on his penis that healed without treatment. Red patches were rise on his both left and right soles since 1 month before, and then become brown patches these 3 weeks. He did not feel itchy, or pain. Literature said that syphilis is usually acquired through sexual contact. After 10 to 90 days after the first exposure, ulcer will arise on the primary lesion $[2,8,9]$. In the absence of treatment, syphilitic ulcers heal spontaneously within 3-6 weeks, with appropriate treatment heal without scar within 1-2 weeks $[2,9]$. Secondary syphilis occurred within 6-8 weeks (up to 6 months after exposure) characterized by rash symmetrically on the trunk and extremities, localized or diffuse. This secondary syphilis rash may also appear before ulcers gone, but sometimes it is very subtle and not so clear $[2,4,5]$.

Physical examination revealed that he had normal status general. Dermatology examination found multiple, oval, discrete, hyperpigmentation macules, no scales. There were painless inguinal lymph node enlargement on both right and left inguinal. Ulcer on the penis or perianal could not be found. Literature say that skin lesions in syphilitic roseola are usually symmetric, can be macules, papules, papulosquamous, and pustules. Patient rarely complaint for itching, inguinal enlarged lymph nodes could be found mostly $[1,4]$.

Literature say that Serologic Test for Syphilis (STS) is an important test for syphilis diagnosis, screening, and assessing the progress treatment of syphilis $[2,6,9]$. There are two types of serology test used to syphilis diagnose, which are non-treponemal test (Venereal Disease Research Laboratory/ VDRL) and treponemal test TPHA (Treponemal Pallidum Haem agglutination) $[2,5,10]$. If therapy is successful, VDRL titer will decrease rapidly. Suspect syphilis is someone with VDRL titer of a quarter or more, while positive result start after two to four weeks since primary syphilis. Its titer will increase until it reaches a peak in stage II. TPHA has quite high sensitivity, around $95 \%$ and will be positive on day of 14 .Serologic test for syphilis in this case are VDRL 1: 64 and TPHA 1: 640 , CD4 counts was 590 cells $/ \mathrm{mm}^{3}$. Serology test taken 3 months post-therapy are VDRL 1: 32 TPHA 1: 640, and 6 six months post therapy are VDRL 1: 4, TPHA 1: 640.

This patient was high risk of HIV infection because of homosexuality and frequent unprotected anal or oral sexual intercourse since 5 years ago. Based on CDC, he was in stage II of HIV, given first line antiretroviral drugs, which were tenofovir, lamivudin, and efavirenz [7]. CD4 before an ARV therapy was under 200 cells $/ \mathrm{mm}^{3}$, the latest CD4after an ARV therapy is 630 cells $/ \mathrm{mm}^{3}$. Viral load test result: not detected (level of detected: $>40$ copies / ml).

Differential diagnosis with tinea pedis can be ruled out. From anamnesis those non itchy brown patches, no history of the foot were often submerged in water. $\mathrm{KOH}$ examination could not be found yields. Literature say that in tinea pedis, patient often complaint itchy, and clinical manifestation can be found macules, papules, vesicles, pustules, maceration or scales. On KOH examination, yield is the highest rate of positive findings [13].

Differential diagnosis with allergic contact dermatitis can be ruled out. Literature says that allergic contact dermatitis is a cell-mediated (type IV), delayed type, hypersensitivity reaction caused by skin contact with an environmental allergen. The hands, feet, and face (including the eyelids) are some of the common sites forallergic contact dermatitis. The feet allergens include rubber, leather, glue potentially presents as components of shoes and slipper. Itch and swelling are key components of the history and can be a clue to allergy. The acute phase is characterized by pruritus, erythema, edema, and vesicles usually confined to the area of direct exposure. Recurrent contact to the allergen in a sensitized individual will result in chronic disease, characterized by lichenified erythematous plaques with variable hyperkeratosis and fissuring that may spread beyond the areas of direct exposure $[14,15]$. This case, patient did not feel itchy on both of his soles. No history of sneezing, urticaria in the morning. No history of new shoes or materials applied on his soles. No history of food or drug allergy. Clinical manifestation of his soles was non scaling hyperpigmentation macules, oval, discrete.

Secondary syphilis can be treated with benzathine Penicillin G intramuscular and single dose of 2,4 million units, or Procaine Penicillin G in aqua 0,6 million units/day intramuscular for 10 days. For person who have allergic to penicillincan be treated with tetracycline $500 \mathrm{mg} 4$ times/ day, or erythromycine $500 \mathrm{mg} 4$ times/day, or doxycycline $100 \mathrm{mg}$ twice daily, for 15 days.

Therapy using 2.4 million units single dose of Benzathine Penicillin G intramuscular provided clinical and serological improvement within 6 months. Literature say that Benzathine penicillin $G$ intramuscular is the recommended treatment for all stages of syphilis, the 
treatment dose dependent on stage of disease and clinical manifestation. The treatment for secondary syphilis with or without co-infection with HIV is an intramuscular and single dose of 2.4 million units of benzathine penicillin $G$ [4,7-11].

This patient's prognosis of quo ad vitam, ad sanam isdubia ad malam, quo ad cosmeticam is ad bonam. Since this patient suffers for HIV, immune system is unable to resist pathogen entry. So that, in addition to a pre-existing STIs could be more severe, recurrent or resistant, patient is in high risk of having another life-threatening infection. Those hyperpigmentation macules would disappear spontaneously.

\section{Summary}

Syphilitica roseola in a 29-years-old unmarried man had been reported. He was complaint non itchy brown patches on his soles. At the beginning, that brown patches were reddish, just a few patches, and getting more in this 3 weeks. Dermatology examination found multiple, oval, discrete, hyperpigmentation macules, no scales. There were painless inguinal lymph node enlargement on both right and left inguinal. No ulcer on his penis or perianal. Serologic test for syphilis in this case are VDRL 1: 64 and TPHA 1 : 640. Therapy using 2.4 million units single dose of Benzathine Penicillin G intramuscular provided clinical and serological improvement within 6 months. The prognosis of this patient isquo ad vitam, ad sanam is dubia ad malam, quo ad cosmeticam is ad bonam.

\section{References}

1. Musher DM (2007) Clinical manifestation of syphilis. In: Holmes KK (Eds.), Sexually transmitted disease $4^{\text {th }}$ (Edn.), McGraw-Hill, New York, pp: 661-674.

2. Stary A, Stary G (2012) Sexually Transmitted Infections. In: Bolognia JL (Eds.), Dermatology: Vol 1 $3^{\text {rd }}$ (Edn.), Mosby Elsevier Science, UK, pp: 1367-1379.

3. Sanchez MR (2012) Syphilis. In: Wolf Klaus (Eds.), Fitzpatrick's Dermatology in General Medicine $8^{\text {th }}$ (Edn.), McGraw-Hill, New York, pp: 2471-2492.
4. Murtiastutik D, Barakbah J, Lumintang $\mathrm{H}$, Martodihardjo S (2008) Syphilis. In: Sexually Transmitted Infections. Universitas Airlangga Press, Surabaya, pp: 136-157.

5. Morton RS, Kinghord GR, Vegas FK (2010) Syphilis and bacterial sexually transmitted infections. In: Burns T (Eds.), Rook's Textbook of Dermatology $8^{\text {th }}$ (Edn.), Wiley-Blackwell, UK, pp: 341-426.

6. Center for Disease Control and prevention (CDC) (2014) Syphilis. In: sexually transmitted disease control surveillance. United State Department of health and human service, Atlanta.

7. Centers for Disease Control and Prevention (2015) Sexually Transmitted Diseases Treatment Guidelines.

8. Chandrasekar PH, Bronze MS (2016) Syphilis.

9. Hutapea NO (2007) Sifilis. In: Djuanda A (Eds.), Infeksi menular seksual $3^{\text {rd }}$ (Edn.), FKUI, Jakarta, pp. 84-102.

10. Ngan V, Vanoisova D (2015) Syphilis.

11. Rompalo A, Hynes AN, Mitty J (2015) Treatment and prevention of syphilis in the HIV-infected patient.

12. Rasmussen SK (2015) Syphilis and HIV co-infection. Danish medical journal 62(12): B5184.

13. Schieke MS, Garg A (2012) Superficial fungal infection. In: Wolf Klaus (Eds.), Fitzpatrick's Dermatology in General Medicine $8^{\text {th }}$ (Edn.), McGrawHill, New York, pp: 2277-2297.

14. Tardan MP, Zug KA (2012) Allergic contact dermatitis. In: Wolff K (Eds.), Fitzpatrick's Dermatology in General Medicine $8^{\text {th }}$ (Edn.), McGrawHill Book, New York pp: 152-164.

15. Weller RB, Hunter HJ, Mann MW (2015) Eczema and dermatitis. In: Clinical dermatology. $5^{\text {th }}$ (Edn.), Blackwell Wiley publishing, United Kingdom, pp: 7698. 